\title{
Hindrance of Mudharabah Financing: A Study from Islamic Banking Industry of Pakistan
}

\author{
Tuqir Afzal $^{1} \&$ Shazia Hassan ${ }^{1}$ \\ ${ }^{1}$ Department of Leadership and Management Studies, Faculty of Contemporary Studies, National Defence \\ University, Islamabad, Pakistan \\ Correspondence: Tuqir Afzal, Department of Leadership and Management Studies, Faculty of Contemporary \\ Studies, National Defence University, Islamabad, Pakistan. Email: tuqirafzal@gmail.com
}

Received: October 1, 2018

Accepted: November 4, 2018

Online Published: November 10, 2018

\begin{abstract}
In spite of the momentous growth of Islamic banking, the equity-based financing, "Mudarabah"(trustee partnership), the most pioneer product of Islamic banking, is still in its infancy. It is evident from the literature that the implementation of Mudharabah based financing is very less compared to other modes of financing. Therefore, this study is conducted to investigate the hindrance factors of Mudarabah financing. After the literature review, qualitative research methods applied to study the effect of Moral Hazard, Operational Difficulties andRisk factors. The findings showed the inverse relation between Mudarabah growth and operational difficulties, signifying that as operational difficulties increased managers discouraging customers not to adopt Mudarabah financing as their first choice. Risk Factors and morals hazards also show the inverse relationship. Findings of the study have practical implications for financial institutions, practitioners, policy makers, and customers.
\end{abstract}

Keywords: Islamic Banking, Mudarabah Growth, Operational Difficulties, Customers Preferences, Risk Factors 1. Introduction

It is evident from last few decades Muslims are trying to reconstruct and organize their lives according to Islamic principles and Shariah guidelines. The Muslim nations felt the tough dominance in economic and political fields by western countries throughout the last century. They tried to manage their political and economic systems according to Islam. But it was not an easy task to build the economic structure as per Islamic laws and ethics in the presence of huge interest based economic system and monetary institutions (Usmani, 2004). The fast grower Malaysia and oil crisis of the 70s give enough stimuli to Muslim Policymakers, Governments and Financial institutions to establish the instruments parallel to westerns instruments according to Shariah. This attempt was without any resentment (Visser, 2009). Last few decades are evidence of this fact that the Islamic banking is growing faster than the conventional banking and currently, total Islamic banking deposits are about 15 billion (PKR) in Pakistan (SBP, 2018), despite this momentous growth of Islamic banking the Mudharabah based

${ }^{1}$ Correspondence author, tuqirafzal@gmail.com 
financing has a very minor share in implementation. Even though it is most preferred by many Muslim scholars for its nature. Mudarabah is well-thought-out as one of the most superior mode of Islamic Finance both by former and current Islamic scholars and jurists (Shaikh, 2011). Presently many Islamic scholars and Shariah boards of different institutions are encouraging the usage of Mudarabah (profit sharing) and musharakah (profit loss sharing) because it carries no interest and gharar factors for the economic activities (Sapuan, 2016). The major reason for the growth of Islamic modes of finance is high return and religious guarantee by many Muslim scholars and shariah board (Visser, 2009). Theoretically, Mudharabah and Musharakah are more preferred modes of finance by Islamic Scholars (Faiz, 2014). The well-known Islamic scholar MaulanaTaqiUsmani mentioned more than 5 times, Mudharabah and Musharakah as a most ideal mode of finance, in his book "Introduction to Islamic Finance" on page 12, 17, 72, 107 and 164 (Usmani, 2004).

\section{Problem Statement}

Despite the growth of Islamic banking, the growth rate of Islamic equity-based financing, "Mudarabah" (trustee partnership) is still in its infancy.

\section{Literature Review \\ 3.1 Mudarabah}

Mudarabah is an Arabic word derivative from Darb (travel), one of its expression is Darb-fil-ard which means travel on the earth, and grammatically it is from Mufa'al chapter which indicates the action of two people. In the business or Law dictionary, it means the mutual contract of two people or parties to start or join a business in which one party is agreeing to provide the capital and other will offer or provide his services for the optimal usage of capital so that the profit can be earned (Qadri, 2007).

In Islamic Finance, equity financing instruments are based on the Musharakah (profit loss sharing) and Mudarabah (profit sharing) principles. These financial modes are used as an alternative to conventional debt financing that is based on interest (riba) rate. These contracts (equity based) comprises a mutual sharing of loss and gains, depending on the return from a project where investment has been made (Sapuan, 2016). There are mainly two parties in Mudarabah contract, one is called as Rab-ul-mal (fund provider) -a person or institute who provide the financial capital and second one is the Mudarib(Manager or entrepreneur) who offer his expertise and service for the optimal use of capital to form a profit-sharing venture. Distribution of profit is predetermined in the contract on the basis of mutual understanding. In the case of failure, all financial losses would be borne by the Rab-ul-mal, on the other side Mudharib will be lost his effort and time (Shaikh, 2011). But if the loss is due to the negligence of Mudharib, he is responsible to bear the financial loss as well (Usmani, 2004).

\subsection{Hindrance Factors \\ 3.2.1 Operational Difficulties}

Managers of Islamic banks sometimes face problems pertaining to the application of Islamic mode financing such problem is known as operational difficulties. Literature relating to operational difficulties suggested that the higher the probability of operational difficulties the lesser will be the growth of Islamic mode of financing (i.e. Mudarabah financing here). As, in operational difficulties managers discouraging customers not to adopt Mudarabah mode of Islamic financing, which in turn lead to the poor growth of Mudarabah financing. Some of these problems include accounting problems, monitoring cost, assessment of projects, lack of managerial skills of Islamic banking staff etc. Taking the same point forward, Al-Haran (1990) highlighted that "equity financing is a highly complex and difficult operation". Islamic banks have a lack of comprehensive institutional infrastructure and support needed to direct it to behave in accordance with the theoretical framework (Errico and Farahbaksh 1998). It was auxiliary explained by El-Hawary et al. (2004) that the poor support of institutional infrastructure exposes Islamic banks to systemic risks comprised of business environment risk, institutional risk, 
and regulatory risk.

Sarker (1999) concludes that the analysis based on the discussion with the senior professionals of Islamic banks that IBs put their utmost effort for selecting efficient and profit-oriented projects but they fail to oversee the post-financing condition in most of the cases.

Maniam et al. (2000) recognize that the problem is revealed in the application of Islamic finance in the Islamic banking industry. Lack of technical staff accustomed to the Islamic system and have inadequate knowledge to improve the application of the ethical and social values of the system.

Thus, based on these arguments it is proposed that operational difficulties are a critical factor in the growth of Mudarabah financing.

\subsubsection{Moral Hazard}

The term Moral Hazard has its roots in the 17th century when it was widely used by Insurance companies by the British insurance industry. Initially this was a negative term referring towards fraud and other unethical acts done by policyholders for claiming the insurance, but later in the 18th century some prominent mathematicians used it as the term 'moral' in the meaning of 'subjective', which may cloud the true ethical significance in the term (Dembe, 2000). It has seemed that a problem of moral hazard may be observed when some individuals through some contract engage in risk sharing under conditions such that their privately taken actions affect the probability distribution of the outcome (Dembe, 2000). While assessing the merits and demerits of conventional and PLS banking it is evident that the PLS banking is the better option than the conventional banking even in the presence of Moral Hazard (Rajash \& Tarik, 2000). Islamic financial system is unable to avoid to "Islamic Moral Hazard" unscrupulous behavior of those engaged in Islamic finance and use the religion as a shield against scrutiny (Warde, 2000). On the asset side of a bank one of the major hurdles in the use of Mudarabah is that only the investor is considered to face all the financial losses, i.e. if Islamic Bank is providing fund in a Mudarabah than in case of failure all losses have to be bear by the bank (Shaikh, 2010). Bacha (1997) highlighted the agency problem as one of the major hurdles in Mudarabah and claimed that it lacks the bonding effect of debt financing and can induce perverse incentives. Similarly, some other researchers like Warde (1999), Dar \& Presley (2000), and Rosly\&Zaini (2008) also pointed out the agency problem in Mudarabah. State Bank of Pakistan also pay attention to this issue and commented that:

"In fact, the agency problem is one of the major factors for the reluctance on the part of banks to undertake equity-based modes of financing, as it gives entrepreneurs the incentive to understate profits." (SBP, 2008).

Shaikh (2011) used a different scenario analysis but got the same results and concluded that the Mudarabah is only beneficial for the company which is seeking the finance but not useful for the Islamic Bank due to moral hazard (Samadzadeh \& Melander, 2012). The major reason for giving less priority to Mudharabah or Musharakah is a presence of Moral Hazard and asymmetric information (Zaher\& Hassan, 2001; Babar, Iqbal, Khan, \& Afzal, 2007).

\subsection{Risk Factors}

Besides the benefits of Mudarabah and Musharkah agreements there are several types of risk involved in their executions i.e. market risk, liquidity risk, credit risk and operational risk (Rahim, 2014). One type of operational risk is Shariah non-compliance risk in which occurs due to the nullification of contracts and as a result, the Islamic Financial Institutes face the financial losses, in Profit sharing contracts like mudharabah and musharakah contracts while allocating the profit based on the expected return (Rosly et. al 2013). The allocation of profit must necessarily take place on the basis of the actual profit earned through an actual or constructive valuation of the sold assets (AAOIFI, 2005). Operational risk can occur when the representer of the IFI don't assess the 
soundness and reliability of the partner due to lack of expertise or negligence (Izhar 2010). Another reason for operational risk may the incompatibility of an accounting system that to fit the framework of Islamic contracts (Safa 2013).

\subsection{Theoretical Framework}

\section{Theoretical Framework}

\begin{tabular}{|l|l|l|}
\hline Moral Hazards & $\longrightarrow$ & $\begin{array}{l}\text { The growth of } \\
\text { Mudarabah } \\
\text { Financing }\end{array}$ \\
\hline Operational Difficulties & $\longrightarrow$ \\
\hline
\end{tabular}

\section{Hypothesis}

H1. There is a negative relationship between Moral Hazard and Growth of Mudarabah Financing.

H2. There is a negative relationship between Risk Factor and Growth of Mudarabah Financing.

H3. There is a negative relationship between Operational Difficulties and Growth of Mudarabah Financing.

\section{Methodology}

As the qualitative methods of research are more suitable for financial researches as qualitative methods like interviews provide a more comprehensive answer to complex questions (Kaczynski, 2013).The qualitative method of research is applied in this research by conducting the interviews to 23 senior officials associated with the Islamic banking industry. The sample was obtained from to major cities of Pakistan, Islamabad, and Rawalpindi. For data analysis the Nvivo-11 qualitative data analysis was used, it does not analyze the data but permit the scholar to identify and read the themes and patterns of qualitative data (Bazeley, 2009).

Data Analysis

\section{Overall Findings}

In this research 23 interviews were conducted from different officials of the Islamic Banking Industry and their reply was documented and exported in the Nvivo, an automatic coding technique was used to identify the themes and sentimental information. Most of the experts relied on the variables identified by the researcher through literature review for research, however, some experts also pointed out some other factors related to this issue, like geographical or cultural patterns, Government Policies, rate or cost of the financing. However major were Moral Hazard, Operational Difficulties and Risk Factors.

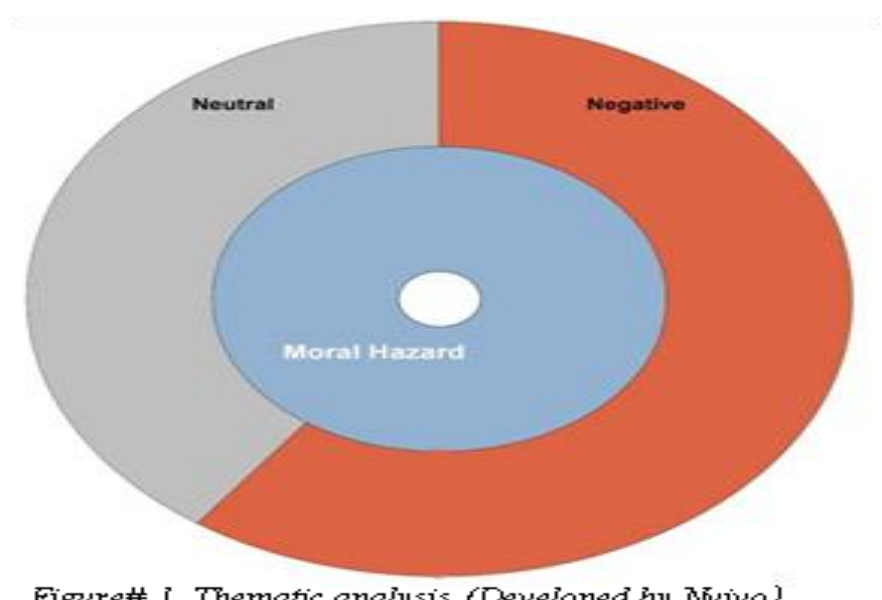

Figure\# I. Thematic analysis (Developed by Nuivo) 


\subsection{Moral Hazard and Mudharbah}

In the answer regarding the Moral Hazard and its effect on Mudharabah the most of respondents reply with negative notions, Nvivo Sentiments theme(as shown in figure\# 1) describe more than half of the portion as negative, which describes the Moral Hazard has the negative influence on the growth of Mudharabah Financing. The remaining portion of the chart express the neutral point of view by the respondents, it describes that the rest of the opinion was neutral in this regard. The above results emphasize that one of the major hurdles of the growth of Mudharabah financing is the existence of Moral Hazard in the financial institutions. Another domain which is identified in Moral Hazard Node in "Experts" \& "Audit System", this domain is a reason behind the neutral respond because of the presence of highly experts and strict audit system prevents or minimize the role of Moral Hazard in this regard. But the presence of Moral Hazard is still in Mudharabah contracts, and due to this presence investors hesitate to invest through Murabaha contracts, which ultimately leads towards its decline or not adaptability this mode.

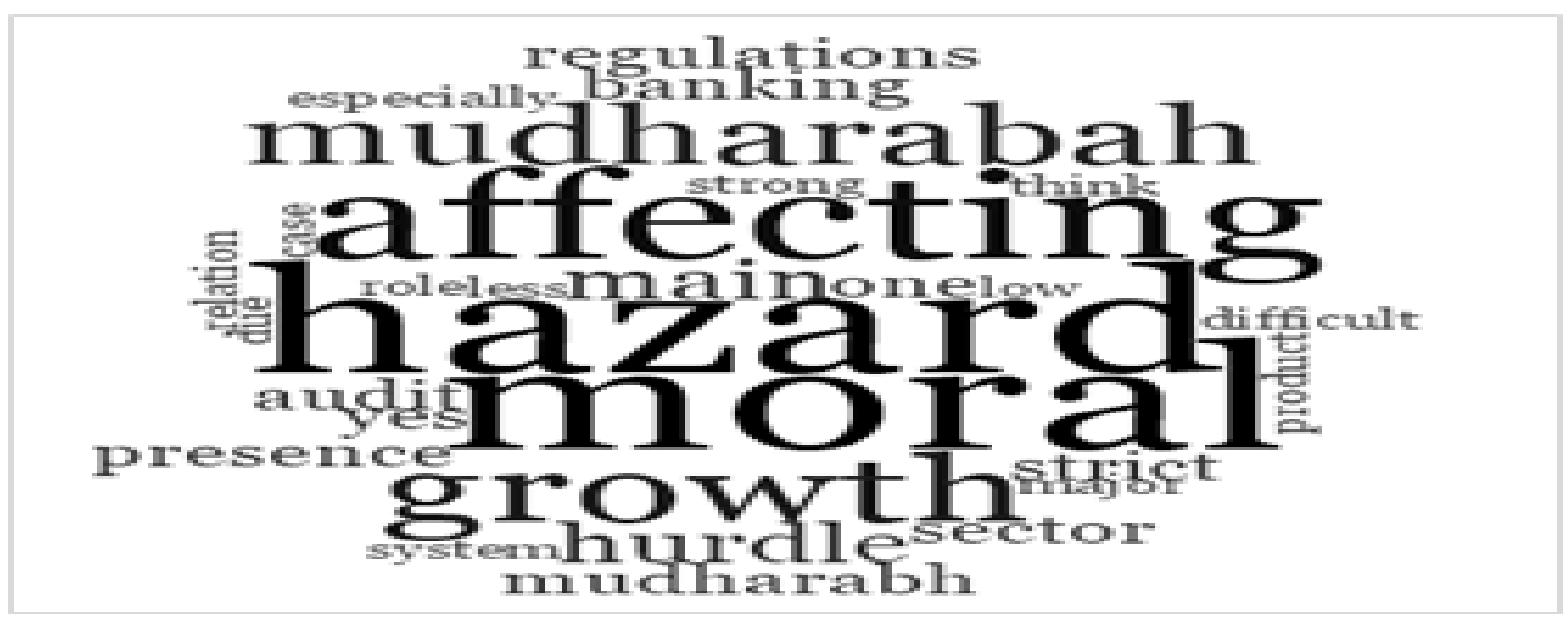

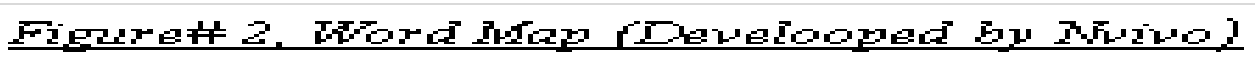

The world map of Nvivo(as shown in figure\# 2) also describes the moral hazard has strongly negative influence on the growth of mudharabah and it is one of the major hurdles but the presence of strict audit system in the banking sector also shown in the map and this ultimately neutralize the role of Moral hazard but to only to some extent. From the above discussion, we can summarize that there is a negative relation between Mudharabah growth and Moral Hazard, even though there exists a strong audit system.

\subsection{Risk Factors and Mudharabah}

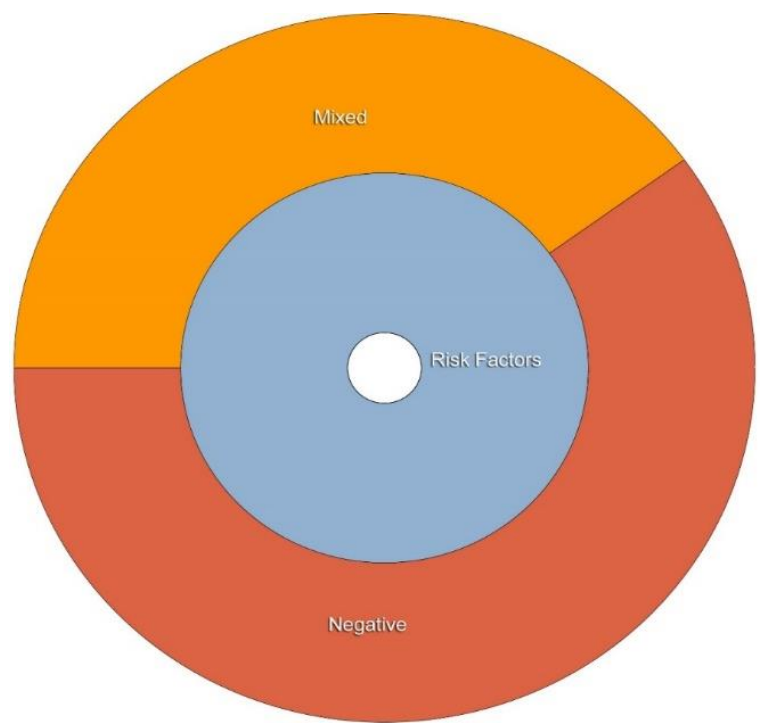

Figure\# 3, Thematic anaOysis (Developed by Nvivo) 
Risk factors include various types of risk in this study, the response of studying sample in this regarding risk factor is mostly negative by the professionals, however, some mixed point of view is also observed during the study. As the figure\# 3 shows the most of the response in this regard was negative but there is also one share of the mixed response, the mixed response is the result of the presence of highly skilled experts of investment who prevents any investment to become riskier.

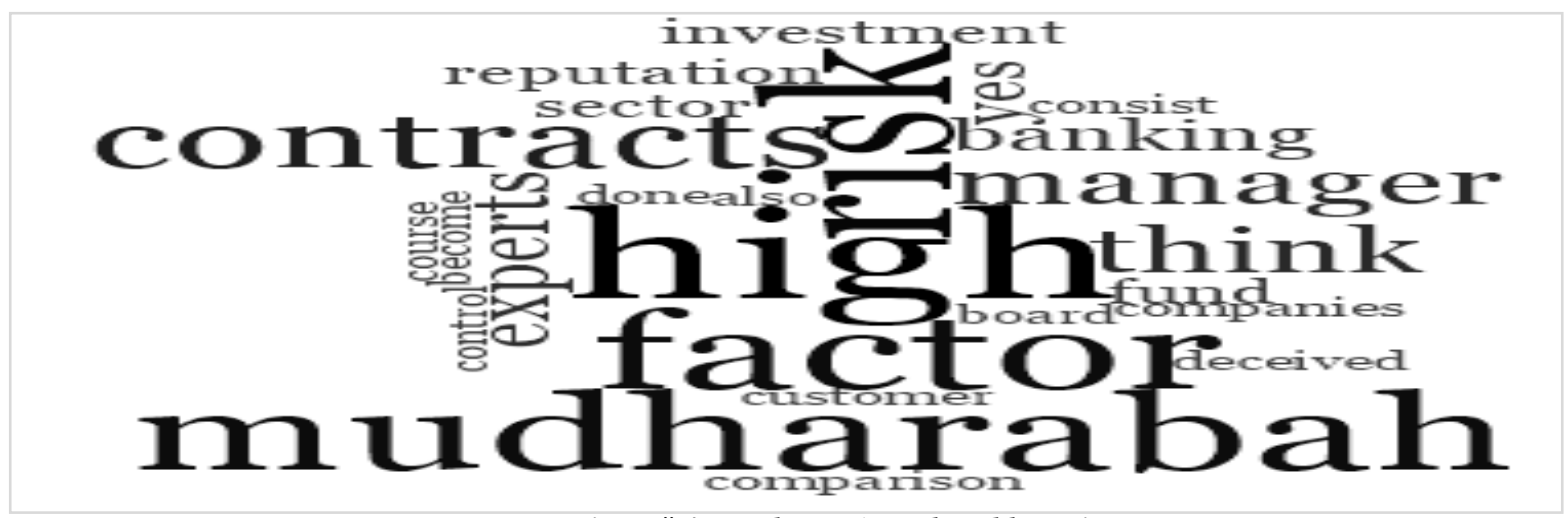

Figure\# 4, Word Map (Developed by Nvivo)

In this research, Risk Factors are appeared as one of the main hurdles or sang which prevents the growth of Mudarabah Financing. Even though banking industry consists of highly skilled experts who manage the resource and scrutinize the whole investment procedure and persons but still there are chances of failure which leads not only towards the financial loss but also towards the loss of reputation, faith, and trust. The world map(figure\# 4) of Risk Factors also depicts that the presence of experts is an advantage but they are also on the risk of reputation in case of a single bad judgment they have to lose their reputation and trust. Above evidence are proved that there is a strong negative relationship between the Mudarabah growth and Risk Factors associated with this contract, however, it can be minimized through financial experts, wise judgments and strict scrutinize system.

\subsection{Operational Difficulties and Mudharabah}

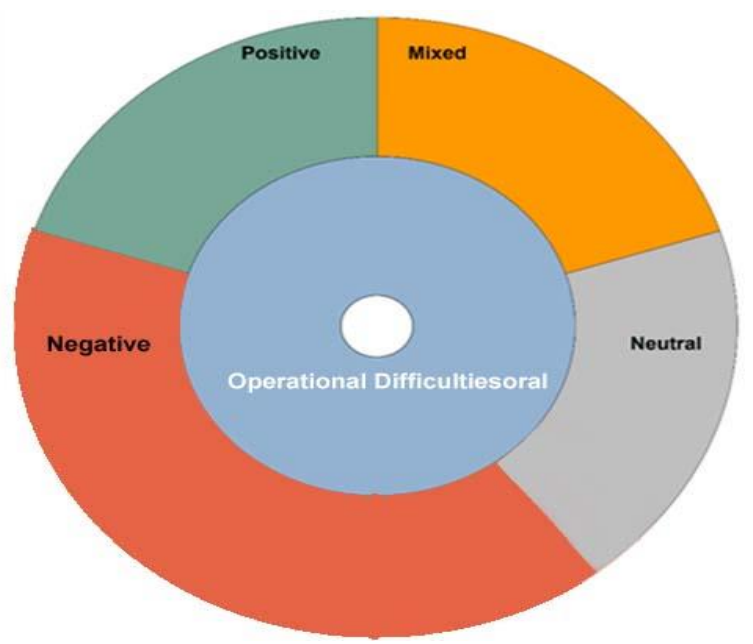

Figure\# 5. Thematic analvsis (Develoned bv Nvivo)

During the interview phase of this research response regarding to the operational difficulties are different than the other variables studied by the researcher, because researcher found most response as neutral (as shown in figure\#5) some portion is extended to as mixed answer, while around one fourth portion found was positive in the response of operational difficulties are more in Mudharabah contracts than other modes of financing. And 
Researcher found this operational difficulty having negative association with Mudharabah Growth, but some respondent's response shows that it also has positive influence on growth because the client due to Shariah compliance understand the procedures of Mudharabah contracts so they positively participate in it, but major response in this regard shows that operational difficulties have not strong association with growth of mudharabah growth. Because banking operations of different products seem to be the same and have no major concern on the client's part.

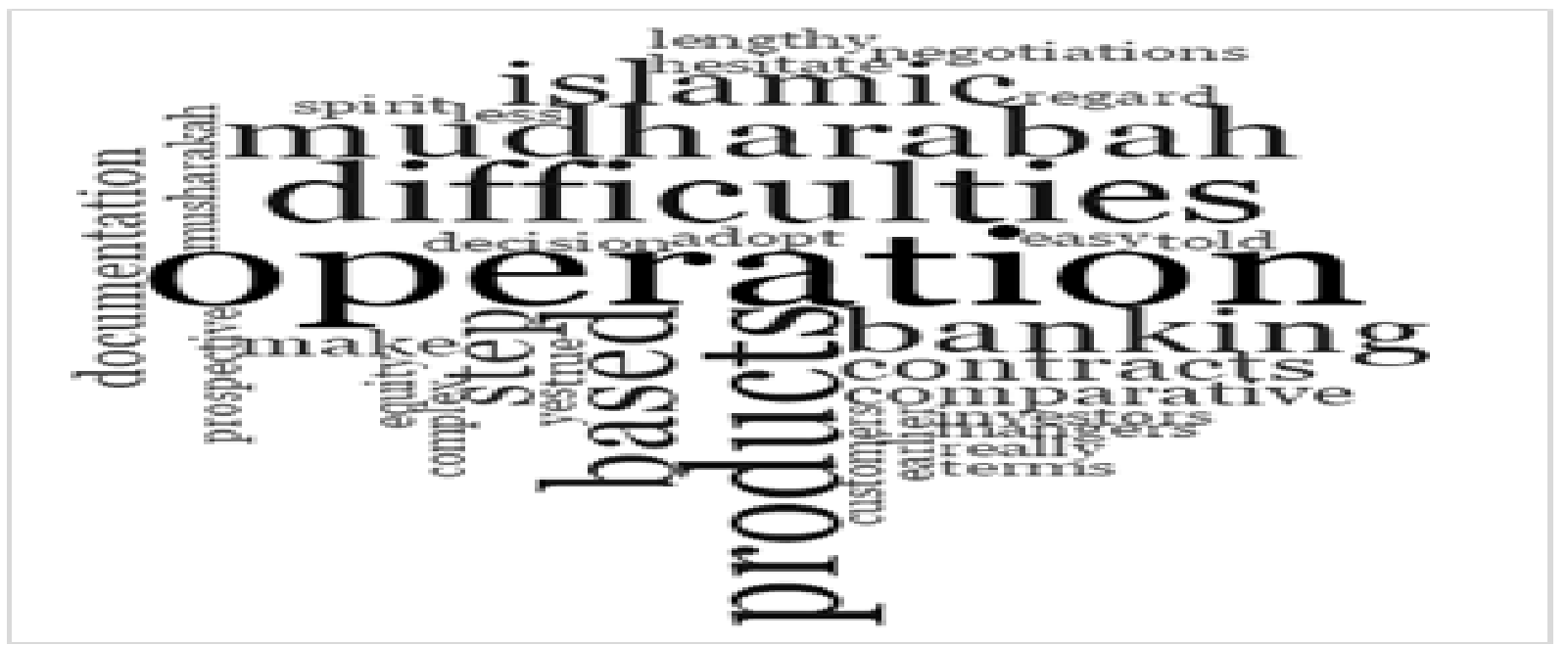

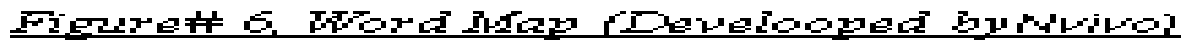

The word map developed through Nvivo shows that in the node of "Operational difficulties" show that documentation, negotiation, comparative contracts, lengthy, hesitation etc. as replication in the response. It simultaneously depicts the response in this regard is mostly neutralized. Above discussion concludes that the there is no strong relationship between the growth of Mudharabh and Operation difficulties, a little bit evidence found it can be cover or it may be due to the different hierarchy level of employees probed during the qualitative research.

\section{Conclusion}

It is revealed from the literature work and interviews conducted, that the operational difficulties and moral hazards are one of the main hurdles for the adoption and growth of Mudharabah financing not only in Pakistan. Operational Risk is also one of the main hurdles in the development of Profit sharing contract Mudharabah as it involves complex procedures and long processes. However, it is depicted that the customers of Islamic Banks are willing to adopt the Mudharabah financing both in deposits and in credits.

\section{References}

A. Mas-Colell, M. W. (1995). Microeconomic Theory.

AAOIFI. (2018, 02 25). History. Retrieved from Accounting and Auditing Organization for Islamic Financial Institutions: http://aaoifi.com/our-history/?lang=en

Bazeley, P. (2009). Analyzing qualitative data: More than 'identifying themes'. Malaysian Journal of Qualitative Research. 2.

Dembe, A. E. (2000). Moral Hazard: A Question of Morality? New Solution: A Journal of Environmental and Occupational Health Policy, 257-279.

Doraisamy, B., Shanmugam, A., \& Raman, R. (2011). A Study on Consumers' Preferences of Islamic Banking Products and Services in Sungai Petani. Academic Research International, 1 (3), 290-302.

Dow Jones Islamic Market Indices - Shariah - S\&P Dow Jones Indices. (2018, 02 25). Retrieved from Dow 
Jones Islamic Market Indices: https://us.spindices.com/index-family/shariah/dow-jones-islamic-market

Faiz, W. (2014). Challenges And Opportunities Islamic Financial Institutions Are Facing In The Western Countries.

Gait, A. H., \& Worthington, A. C. (2009). Attitudes, Perceptions, and Motivations of Libyan Retail Consumers toward Islamic Methods of Finance. Paper presented to the Asian Finance Association 2009 International Conference, Brisbane, 30 June- 3 July.

History of Islamic Banking. (2018, January 14). Retrieved from State Bank of Pakistan.

Ismal, R. (2013). Islamic Banking in Indonesia: New Perspectives on Monetary and Financial Issues. John Wiley \& Sons.

Kaczynski, D. \&. (2013). Qualitative Research in Finance. Australian Journal of Management. 39. 127-135. $10.1177 / 0312896212469611$.

Kaleem, A., \& Rahmatullah. (2005). A Study of Young Customers' Preferences for Bank Selection in Pakistan. Journal of Independent Studies and Research (JISR), 33-38.

Khan, S, M., Mirakhor, a., \& Abbas. (1987). Theoretical Studies in Islamic banking and Finance. Houston. Texas: The Institute for Research and Islamic Studies.

Kontot, K. (2016). Determining Factors of Customers' Preferences: A Case of Deposit Products in Islamic Banking. 6th International Research Symposium in Service Management, (pp. 167-175). Kuching, Malaysia: Procedia - Social and Behavioral Sciences 224.

Krugman, P. (2009). The Return of Depression Economics and the Crisis of 2008. W.W. Norton Company Limited. ISBN 978-0-393-07101-6.

Pauly, M. V. (1968). The economics of moral hazard: comment. The American Economic Review. American Economic Association. 58 (3):, 531-37.

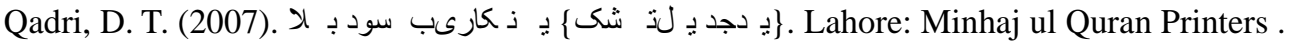

Rahim, A. M. (2014). Operational Risks in Islamic Profit Sharing Contracts and Ways to Overcome Them. INCEIF.

Rajash, A., \& Tarik, Y. (2000). Islamic Banks and Investment Financing. Journal of Money, Credit, and Banking.

Samadzadeh, N., \& Melander, H. (2012). The Implications of Agency Theory on Mudarabah and Musharakah Agreements. Thesis Stockholm School of Economics.

Sapuan, N. M. (2016). An Evolution of Mudarabah Contract: A Viewpoint From Classical and Contemporary Islamic Scholars. Procedia Economics and Finance 35, 349 - 358.

SBP. (2018). Islamic Banking Bulletin. Karachi: SBP.

Shaikh, S. A. (2011). A Critical Analysis of Mudarabah \& A New Approach to Equity Financing in Islamic Finance. Journal of Islamic Banking \& Finance, ISSN 1814-8042.

Usmani, M. M. (2004). An Introduction to Islamic Finance. Kluwer Law International.

Visser, H. (2009). Islamic Finance Principles and Practice. Edward Elgar.

Warde, I. (2000). Islamic Finance in the Global Economy. Edinburgh University Press.

\section{Copyrights}

Copyright for this article is retained by the author(s), with first publication rights granted to the journal.

This is an open-access article distributed under the terms and conditions of the Creative Commons Attribution license (http://creativecommons.org/licenses/by/4.0/). 